\title{
The evolution of public administration models
}

\author{
Marian Kachniarz \\ Wroclaw University of Economics \\ Wroclaw, Poland \\ marian.kachniarz@ue.wroc.pl
}

\author{
Arkadiusz Babczuk \\ Wroclaw University of Economics \\ Wroclaw, Poland \\ arkadiusz.babczuk@ue.wroc.pl
}

\author{
Zbigniew Piepiora \\ Wroclaw University of Environmental \\ and Life Sciences \\ Wroclaw, Poland \\ zbigniew.piepiora@up.wroc.pl
}

\begin{abstract}
The paper presents the review of organization and governance concepts influencing public administration. It analyzes the main characteristics of a law-governed state, ideal bureaucracy, new public management, public governance, including the NeoWeberian State. The conducted analysis results in a conclusion that in spite of administration being perceived as a relatively stable system it is subject to an extensive dynamics of paradigm changes. It results from the continuous search for optimal solutions in terms of an organization and its functioning.
\end{abstract}

Keywords - public administration, new public management, public governance, Neo-Weberian State

\section{INTRODUCTION}

The term "administration" originates from the Latin word ministrare meaning to serve (ad, in fact, just strengthens this menial sense) and in the living European languages has been present since Middle Ages. Administrare could mean to provide services, but in the course of time also to manage or even to govern.

In the tradition of Roman languages the meaning of administrare is limited to public governance. In the AngloSaxon tradition this concept is primarily understood as managing any issues - those of an individual, a private institution, church structure, the state or any other public institution. For this reason, in the discussed cultural circle, the term "public administration" was adopted in relation to public governance, also more and more frequently applied in the languages on the European continent [1].

As J. Supernat pointed out, administration means a kind of service or executive activity performed for the benefit of someone or something more important. In case of public administration it refers to serving the political power, i.e. ultimately - in democratic legal states - service for the public good also called common good (its legal manifestation takes the form of public interest determined by time, place and all sorts of actual circumstances, as well as serving the law [2].

The analysis of concepts related to public administration reveals different approaches to its scope and role. Therefore, the purpose of the article is to analyse various models of public administration resulting from both historical and systemic conditions. At this background, in the final part of the presented article, it has been attempted to classify Polish public administration.

\section{DEVELOPMENT}

The beginnings of modern administration have always been connected with an absolute state transformation into the one based on legal norms and democratic rules. These transformations were particularly dynamic in the $19^{\text {th }}$ century under the influence of liberal doctrines, aimed at protecting an individual against the lawlessness of those at power and their administration. Along with such changes the process of local government institutionalization was initiated by e.g. developing dual nature of administration, i.e. central and local government.

M. Weber exerted a fundamental impact on the development of administration model at that time, since he created the concept of impersonal power functioning rationally, based on qualified personnel and executing effectively its tasks based on the commonly adopted procedures and legal norms [3]. The concept created by Weber is referred to in the subject literature as the model of ideal bureaucracy or as a bureaucratic model. Weber assumed e.g. that administration based on impersonal regulations can ensure its functioning efficiency through stability, strict discipline and predictability of effects. Qualified staff as well as specialization and division of work are supposed to ensure impartiality, effectiveness and professionalism.

Weberian bureaucracy was the dominating paradigm of public administration till the 50 s of the $20^{\text {th }}$ century. It, however, did not present uniform nature in all countries worldwide. Its diversification resulted from the so-called national public administration models. While in the continental states (Germany, France) classical Weberian rule were applied, the Anglo-Saxon countries (England, The United States) maintained a relatively larger role of extra-legal rules in the functioning of administration. It was manifested by e.g. more extensive autonomy of those at power in terms of decision-making and the resulting higher responsibility for their economic aspect.

The dynamic socio-economic transformations, which occurred in the second half of the $20^{\text {th }}$ century, resulted in e.g. the development of active attitudes of citizens against the state and its structures. At this background the discussions about public administration form and its functioning methods intensified. M. Weber's approach to understanding bureaucracy was subject to extensive criticism. It resulted from the fact that in practice administration was far from his idealistic visions and principles which it was supposed to 
follow. The fundamental polemics with such theory had already been undertaken in the 60s by M. Crozier [4] who emphasized both dysfunctional and slow functioning of bureaucracy, as well as its focus on achieving benefits by bureaucrats themselves.

The 70s of the previous century were abundant in many negative economic phenomena manifested by slower economic growth, intensification of inflation, higher unemployment rate and the increasing problems in balancing public spending. The crisis of welfare state brought about suggestions that the public sector is too large, ineffective and imposes excessive tax burdens on citizens. Neoliberals claimed that the model of state featuring a large public sector cannot function any longer. At this background the concept of a minimal state was developed, in which the majority of public services were to be be rendered by an entrepreneurial system based on competition and market [5].

One of the main representatives of such approach was W. Niskanen, the author of numerous models analysing public administration [6]. Many European researchers, however, noticed that this theory, by concentrating on principal - agent relations, in fact refers primarily to the American institutional system [7]. The criticism of bureaucracy also resulted from the theory of public choice which emphasized its inefficiency, corruption and the phenomenon of the so-called rent-seeking [8].

The concept of new public management (NPM), also referred to as managerial public management, was developing under the influence of the above-mentioned criticism [9]. This concept was relatively quickly recognized as managerial revolution, a universal model for public sector management, a new paradigm of this sector management [10]. It propagated e.g. the reduction of public sector's role in economy and the transformation of public administration towards searching for savings, public services outsourcing or their privatization, introduction of management methods which were well established in the private sector, upgrading efficiency and effectiveness.

Such leaders as M. Thatcher and R. Reagan represented symbols of the discussed trends - both of them postulated to reduce the role of the state as the leading component of their political image [12]. It was followed by the implementation of new public management in the administration of Anglo-Saxon countries. New Zealand, Australia and Canada followed Great Britain and The United States in carrying out extensive reforms. In the 90s this trend also reached the continental Europe and other OECD countries. As P. Modzelewski observes, the NPM concept turned out an "inspiration" for the numerous countries worldwide which were reforming their administration [13]. A lot of incentives for the authors of reforms were also provided by such publications as To govern differently by D. Osborne and T. Gaebler [14], as well as The key to better management by E.S. Savas [15]. The leading motive taken up by the authors of the first book is the idea of administration limited to "steering" rather than "rowing". Savas, on the other hand, presents the examples of savings made as a result of public services privatization.
In practice the concept of NPM is not homogenous. Firstly, it results from the differences in priorities to be observed in particular countries. While in Anglo-Saxon countries, carrying out the neoliberal policy of modernization, the emphasis is placed on separating public tasks from the state, Scandinavian countries e.g. focus on adequate creating conditions for competition and free choice. The researchers analysing administration problems define the Scandinavian stream as "the regime of management focused on results" [16]. Secondly, NPM is subject to ongoing modifications under the influence of current experiences in its implementation. Within the framework of this stream many studies were conducted, aiming at more detailed assessment of public spending efficiency. They included e.g. unit costs of public services [17], soft budget constraints [18] or even the justification of expenditure for the liquidation of the consequences of natural disasters [19].

The analysis of various NPM models allows to perceive their gradual evolution from the simplified stricte neoliberal concepts towards considering complicated determinants of public sector functioning. In the course of time the way of thinking was changing. The paradigm of public sector slimming, following which private was always considered better and more efficient, was gradually substituted by the idea of public institutions improvement. In the light of the above the term new public management should be rather approached as a broad tendency for administration modernization rather than its direction defined by means of specific characteristics.

The assessment of reforms' effects carried out based on NPM principles remains ambiguous. While the advocates of such reforms pay attention to the reduction of public services costs, their opponents indicate that this effect is frequently achieved at the cost of their poorer quality. The British can serve as the example since they have quickly modified their opinions regarding savings in public services. The tendency towards choosing the cheapest companies resulted in the fact that local governments started providing low-quality public services. Contracts were expensive because they incurred very high transactional costs. It resulted in less money to be spent on the actual service provided. Negative assessment of the implemented reforms ended almost two decades of conservative governments (under the leadership of $\mathrm{M}$. Thatcher and J. Major [20]. Very interesting assessments of the effects of local government reforms implemented in New Zealand and Australia was carried out by B. Dollery. The consolidation of administrative units motivated by NPM ideas brought about counterproductive effects - after 20 years from the reform implementation the costs of local government functioning increased by $20 \%$. Similar results were recorded based on the efficiency analysis of particular public services in the local scale [21].

The complexity of this assessment refers to both microeconomic results and macro scale effects. Zalewski is of the opinion that NPM brings beneficial effects (better efficiency and quality of services) only in relation to simple services, measurable in quantity and value, the quality of which can also be relatively easily evaluated. However, in 
terms of social services, presenting complex structure and diversified goals, NPM can, apart from positive economic effects, result in adverse social consequences [22]. The disappointment in NPM effects is also expressed by the great supporters of this stream [23].

The criticism of NPM effects resulted in larger interest in the trends based on the theory of public choice, new institutional economy and the theory of systems. Their common feature is attracting attention to microeconomic functioning conditions, the role of processes occurring inside public institutions and the importance of informal and immaterial forms of capital. The resulting practical direction in administration reforming is referred to as public governance, explained by Hausner as participatory public management [24]. According to Kooiman's definition, governance can be approached as the pattern of conduct or a structure emerging in the socio-political system as a joint result or the consequence of the interventionist efforts involving all its active participants remaining in an interaction [25]. The subject literature provides many opinions claiming that it is yet another NPM stream. In spite of common elements these two trends in public governance are distinctively different from each other and should be analysed separately [26]. While NPM is based on a contract, public governance follows the rules of partnership.

The continuous interactive contact with citizens (not limited to election only) remains the fundamental premise for administration functioning in line with this model, which results in the systemic integration of the activities performed within the local social system. This concept means the return to the idea of stronger ties between administrative structures and the public sphere owing to legitimization and responsibility. It covers distancing from hierarchical management based on compulsion towards broad coordination and cooperation of independent entities, represented in the local system by e.g. social organizations, private businesses and also natural persons. The functioning of modern societies, based on a democratic system and marketing economy, is characterized by many contradictions and structural problems. Their successful solving is possible only following the path of joint governance. Therefore, the focus should be placed not as much on administrating, but rather on problem solving. This, on the other hand, requires from the state to refrain from imperative ruling and shift towards interactive governance [27].

T. Blair's government was a good example of the formation of institutional partnership [28]. So far the British remain the leaders in the implementation of public governance principles. This stream also covers the concepts of Big Society by the Prime Minister David Cameron, which aim at handing over power and money to the active social groups. Experts refer to this tendency as the largest modernization plan of the British society, even larger than Margaret Thatcher's reforms [29]. Whether it works out in other countries depends, however, on the institutional conditions related to the characteristics of public administration and its experiences in cooperating with other sectors. The implementation of NPM principles has already illustrated how important the national context of administration is - the solutions which worked exceptionally well in one country did not necessarily bring about the intended effect in another one. Therefore, institutional context is even more important in public governance, where the functioning of administration depends more on soft law, influenced by the nature of social relations, public activity, civic initiatives, or finally the ethics of governance.

The concept of joint governance also has its weak points. Those particularly emphasized are as follows: institutional blurring of responsibility, network inability of selforganization, the requirement of presenting high and versatile competencies by the network actors, communication problems, cultural barriers, time-consuming nature, fragmentation of governance processes, poor evaluation mechanisms [30].

This criticism gave way to the concept of modern bureaucracy, which was called New-Weberian State by its authors. It emphasizes the special status of the state which, in accordance with this concept, is indispensable and should remain strong. It clearly indicates distancing from the idea of a minimal state. Its primary assumption is the combination of the elements of traditional Weberian ideal bureaucracy with the selected components of public governance. In this concept Weberian elements refer to: the role of the state as the leading factor responsible for introducing solutions in response to changes in the environment, the role of representative democracy legitimizing the state apparatus, the role of law safeguarding the rules of a citizen-state relationship and the idea of public service with a distinguished status, culture and functioning conditions [31]. The above-mentioned components constitute the background for the functioning of modern bureaucracy developing new (neo) characteristics such as: changing orientation from the perspective of correct execution of its tasks regulated by law into meeting the needs of citizens, applying various consultancy techniques, paying attention to management by results in resource management and professionalization of public service manifested by changing the competencies of officials from legal experts into managers.

The evolution of particular paradigms in public sector functioning was very clearly presented by Izdebski, who divided it into four stages of development [32]. E. Wojciechowski also listed the synthetic characteristics differentiating the model of ideal bureaucracy and public governance [33]. The first two paradigms reflect the Weberian model of ideal bureaucracy, the following two remain significantly different and are best defined by the concept of "public governance", whereas the paradigm of Neo-Weberian Bureaucracy is placed in between these two models.

\section{CONCLUSIONS}

In the summary of the above presented discussion it can be concluded that the development of ideas regarding the method of public administration organization remains the expression of cumulative evolution of thought and administrative practice: from simple schemes, typical for the German rechtsstaat, or 
Henri Fayol's thoughts, to the complex, in its own way, postmodernist perception of the role of administration in public governance. From administration (typical for the Weberian bureaucratic model) to governance, from hierarchical to interactive and diversified structures.

At the background of these considerations it is worth undertaking further reflections on the situation of public administration in a particular country. Does the applicable institutional nature bring it closer to ideal bureaucracy or rather to public governance stream? It particularly refers to the countries which are experiencing systemic transformations. Some researchers are of the opinion that in such countries (e.g. Poland), where the basics of civil service functioning have been missing for many decades, more flexible and less publiclaw (i.e. market oriented) solutions cannot be introduced from the start. First the classical solutions should be implemented, to be followed, in the course of democratic institutions and civil service solidification, by more flexible and already functioning solutions [34]. They are, however, still at the beginning of public administration ethos development, based on governance determined by values [35].

\section{REFERENCES}

[1] J. Hausner (ed.), Administracja publiczna [Public administration], PWN [Polish Economic Publishers], Warsaw 2006, p. 13

[2] J. Supernat, Pojęcie administracji publicznej [The concept of public administration], „Przegląd Prawa Publicznego" ["The Review of Public Law"] 2007, no. 12, pp. 9-15

[3] M. Weber, The theory of Social and Economic Organization, The Free Press, New York 1965, s. 328;

[4] M. Crozier, Biurokracja. Anatomia zjawiska [The bureaucratic phenomenon], PWE [Polish Economic Publishers], Warsaw 1967 (English edition 1964), pp. 16-23

[5] M. Bevir, Public Governance, vol.1, Theories of governance, SAGE, London 2007, p. 22

[6] W. Niskanen, Bureaucracy and Representative Government, AldineAtherton, Chicago 1971

[7] P. Modzelewski, Administracja samorzadowa jako dobro publiczne [Local government administration - public good], [in:] J. Kleer (ed.), Samorząd lokalny - dobro publiczne [Local government - public good], CeDeWu, Warsaw 2008, p. 156

[8] J. Siwińska, Ewolucja sfery publicznej w gospodarce [Evolution of public sphere in economy], [in:] J. Wilkin (ed.), Teoria wyboru publicznego [Public choice theory], Scholar, Warsaw 2005, p. 37

[9] J. Hausner, Zarzadzanie publiczne [Public governance], Scholar, Warsaw 2008, p. 24

[10] H. Bauer, Koncepcje modernizacji administracji publicznej w XXI wieku [Concepts of public administration modernization in the $21^{\text {st }}$ century]. In: Efektywna polityka i administracja [Effective policy and administration]. The Association of Polish Cities, Osterrechische Stadtebund, KDZ- Centrum fur Verwaltungsforchung. Poznań 2005;

[11] J.F. Nowak, Modernizacja lokalnej administracji publicznej a rozwój lokalny [Modernization of local public administration vs local development]., Poznań University of Economics, Poznań 2006, p. 42;

[12] J. Siwińska, Ewolucja... [Evolution...] op. cit., p. 38

[13] P. Modzelewski, Administracja samorządowa jako dobro publiczne [Local government administration as a public good], [in:] J. Kleer (ed.),
Samorząd lokalny - dobro publiczne [Local government - public good], CeDeWu, Warsaw 2008, p. 158

[14] D. Osborne, T. Gaebler, Rządzić inaczej. Jak duch przedsiębiorczości przenika i przekształca administrację publiczną [To govern differently. How the spirit of entrepreneurship pervades and transforms public administration], Media Rodzina, Poznań 1995.

[15] E.S. Savas , Prywatyzacja, klucz do lepszego rządzenia [Privatization the key to better governance], PWE [Polish Economic Publishers], Warsaw 1992

[16] F. Naschold, J. Bohumil, Modernisierung des Staates. Opladen 1998.

[17] M. Kachniarz, Efektywność usług publicznych - teoria i praktyka [The efficiency of public services - theory and practice], Wrocław University of Economics Publishing House, Wrocław 2012

[18] A. Babczuk, M. Kachniarz, Sources of soft budget constraints in the structure of autonomous public healthcare centres, "Argumenta Oeconomica" 1 (28)/2012, pp. 181-214; J. Kornai, The Soft Budget Constraint, „Kyklos” 1986 vol. 39, no. 1, pp. 3-30;

[19] Z. Piepiora, M. Kachniarz, A. Babczuk, P. Piepiora, Counteracting Natural Disasters' Effects in Subcarpatian Voivodeship, Hradec Economic Days 2015, Gaudeamus, Hradec Kralove 2015

[20] P. Modzelewski, System zarządzania jakością a skuteczność i efektywność administracji samorządowej [Quality management system vs. effectiveness and efficiency of local government], CeDeWu, Warszawa 2009, p. 26

[21] B. Dollery, L. Crase, A. Johnson, Australian local government economics, University of New South Wales, Sydney 2006, pp. 139-153

[22] A. Zalewski, Reformy sektora publicznego w duchu nowego zarządzania publicznego [Public sector reforms in the spirit of new public governance], [in:] A. Zalewski (ed.), Nowe zarządzanie publiczne w polskim samorządzie terytorialnym [New public governance in Polish local government], Warsaw School of Economics, Warsaw 2007, p. 65

[23] S.P. Osbourne, Z. Radnor, L. Vidal, T. Kinder, A sustainable business model for public service organization?, "Public Management Review" 2014, vol. 16, No 2, pp. 167-168

[24] J. Hausner, Zarzqdzanie publiczne [Public governance], Scholar, Warszawa 2008, p. 24

[25] J. Kooiman, Modern Governance. New Government-Society Interaction, Sage Publications, London 1993, p. 258

[26] J. Hausner, Zarzadzanie... [Public...] op. cit., p. 24

[27] J. Hausner, Zarzadzanie... [Public...], p. 426

[28] P. Naughton, David Cameron: join me and govern Britain "The Times" 2010, 12 kwietnia 2010.

[29] M. Zawicki, Krytyka konceptualnych fundamentów współzarządzania [Criticism of conceptual foundations of co-governance], in: S. Mazur (ed..), Współzarządzanie publiczne [Public co-governance], Scholar, Warsaw 2015.

[30] C. Pollitt, G. Bouckaert, Public management reform: a comparative analysis: new public management, governance, and the neo-Weberian state, ed. 3, Oxford University Press, Oxford; New York 2011.

[31] H. Izdebski, Introduction to Public Administration and Administrative Law, Liber, Warsaw 2006

[32] E. Wojciechowski, Zarządzanie w sektorze publicznym - od modelu tradycyjnego do governance [Public sector management - from a traditional model to governence], [in:] D. Strahl (ed.), Gospodarka lokalna i regionalna w teorii i praktyce [Local and regional economy in theory and practice], Research Papers published by University of Economic in Wrocław no. 1164, Wrocław 2007, pp. 589-600

[33] H. Izdebski, M. Kulesza, Administracja publiczna. Zagadnienia ogólne [Public administration. General problems], Liber, Warsaw 2004

[34] B. Kudrycka, Etos urzędniczy [Clerical ethos], [in:] A. Dębicka, M. Dmochowski, B. Kudrycka (ed.), Profesjonalizm $w$ administracji publicznej [Professionalism in public administration], The Association of Public Administration Education, Białystok 2004, p. 209 